\title{
Traditional use of Dasylirion acrotrichum in the Construction of Floral Arches for the Festival of San Jerónimo, in Coatepec, Veracruz, Mexico
}

\author{
Guadalupe Torres-Martínez ${ }^{1}$, Citlalli López Binnqüist ${ }^{1}$, Evodia Silva Rivera ${ }^{1}$, and Noé Velázquez-Rosas ${ }^{1^{*}}$ \\ ${ }^{1}$ Centro de Investigaciones Tropicales, Universidad Veracruzana, Xalapa, Veracruz, Mexico. \\ ${ }^{*}$ nvelazquezro@gmail.com
}

\begin{abstract}
In Mexico, floral arches are commonly constructed as offerings in religious festivals. The plants required for fabrication of these arches are currently in great demand, which could affect the species involved. The objective of this study was to document the traditional management of Dasylirion acrotrichum (cucharilla) as used in the construction of floral arches during a festival of great religious and community significance held every year in Coatepec, Veracruz, Mexico. The construction method of floral arches was documented, and the possible repercussions of this practice on the wild populations of this species were analyzed. In Coatepec, the mayordomía is a non-rotational traditional organization system, through which each arch is produced. This system guides the construction activities of the floral arch, which are shared among different actors with various degrees of experience and responsibility. We reveal that between 250 to 270 plants (ultimately using around $60 \%$ of this number) are used to produce the main arch. Likewise, it was documented that during plant collection there are rules observed to avoid extraction of juvenile specimens, especially those that do not have the quantity or quality of leaves required. The social, ritual, and ecological basis of the mayordomía represent an opportunity to build a strategy aimed at regulating the extraction of culturally relevant plant species, and it can also help to improve collection techniques and to encourage sustainable management. That is why we argue that Dasylirion acrotrichum must be understood and studied from a systemic, interdisciplinary perspective.
\end{abstract}

Received January 14, 2020

OPENӘACCESS

Accepted July 30, 2020

Published September 15, 2020

DOI 10.14237/ebl.11.1.2020.1673

Keywords Culturally significant plant, Biocultural resource extraction, Religious offerings, Traditional community institution

Copyright (c) 2020 by the author(s); licensee Society of Ethnobiology. This is an open-access article distributed under the terms of the Creative Commons Attribution-NonCommercial 4.0 International Public License (https://creativecommons.org/licenses/by-nc/4.0), which permits non-commercial use, distribution, and reproduction in any medium, provided the original author and source are credited.

\section{Introduction}

Many Mexican religious festivals use plants to make offerings. They have been offered since pre-Hispanic times as a tribute to the nobility. They symbolized prestige and represented the wealth of the indigenous high society (Mendoza-Zaragoza 2010). These offerings consisted of carpets, garlands, crowns, collars, and arches, which were made with leaves of maize, and wild and cultivated flowers, as well as bird feathers. With the Spanish conquest and adoption of the Catholic faith, the tradition was modified, and thus the offerings began to be made in honor of Catholic saints in religious festivals (MendozaZaragoza 2010). The priests organized groups of the faithful into mayordomias, or "people's commissions," to collect the donations required to financially support the organization of the festivities. The mayordomia is a traditional community institution that originally served as a mechanism to ensure that people were kept at the same socio-economic level by preserving social exchange and cooperation and to strengthen links and commitments within the community (Korsbaek 1987). The mayordomo is a male of moral prestige in the community; he must show appreciation and respect for the church and its patron saint. It is also necessary for him to have access to sufficient economic resources to meet the costs incurred by this responsibility.

Offerings in the form of arches allude to the European triumphant arches that marked the entrance of a noble or deity (Madrazo and Urdapilleta 2008). In Mexico, the floral arches of today are the result of syncretism between Catholicism and pre-Hispanic 


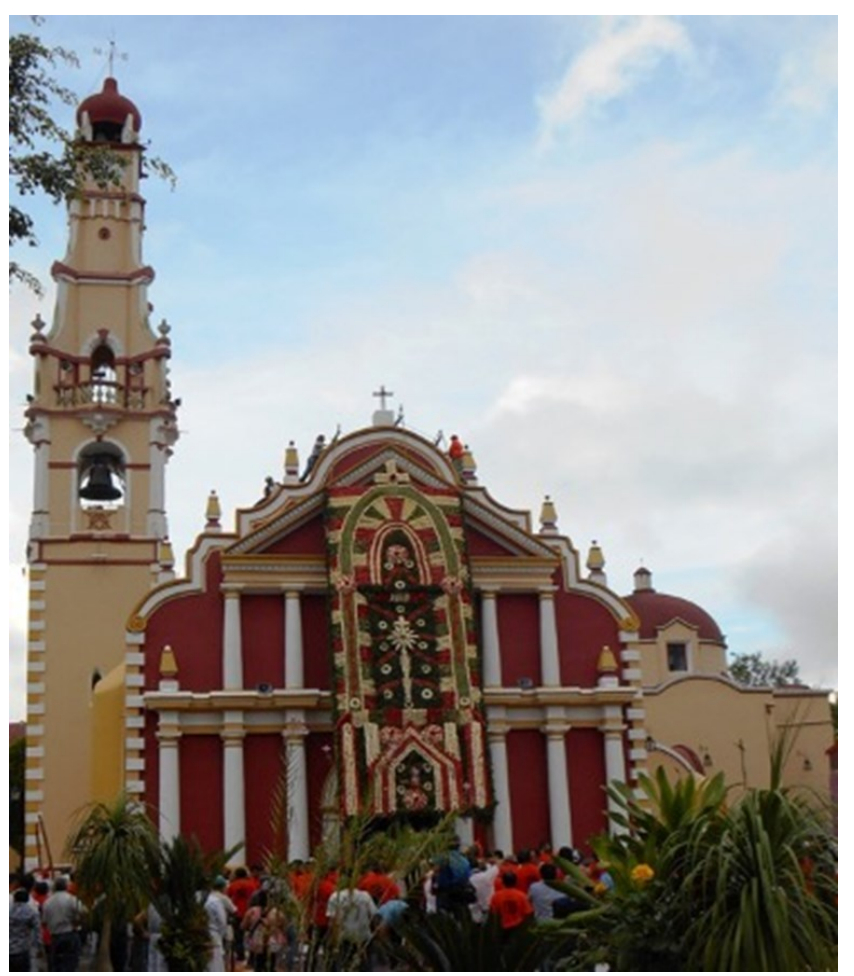

Figure 1 Floral arch adorning the main entrance of the parish church in the annual patronal festival of San Jerónimo in Coatepec, Veracruz.

indigenous tradition (Chiva-Beltrán 2012). For the indigenous and mestizo people, these offerings are a spiritual link between man and the divinities, representing the source of reciprocity between the petitions of mankind and the sacred world (GómezMartínez 2013). At present, in some patronal festivals of central Veracruz, floral arches are the main offering made by the people to the saints in gratitude for blessings received during the year. During these patronal festivals, the "mayordomia" system of organization remains in practice.

In the annual patronal festival of San Jerónimo, which takes place on September 29 in Coatepec, Veracruz, an arch, known as the arco mayor, is constructed to adorn the main entrance of the parish church (Figure 1). This arch is the largest and most important offering of the festival and is constructed using plants collected in the surrounding area, including pine (Pinus spp.), bamboo (Arundo donax), vine (Vitis spp.) and liquidambar (Liquidambar styraciflua), which are utilized in the structure of the arch (Figure 2a). The adornments of the arch consist of the inflorescences of heliconias (Heliconia spp.), bromeliads (Tillandsia multicaulis, T. punctulate, and T. usneoides), cypress leaves (Cupressus spp.), and the "cucharilla" or great desert spoon (Dasylirion acrotrichum) (Haeckel 2008; Torres-Martínez 2016; Figure 2b). D. acrotrichum has for decades been extracted from Alchichica, Puebla, since it grows exclusively in the semiarid regions of Mexico.

In Coatepec, the tradition of the floral arches is a source of pride and identity. This is why it has been integrated as an offering in other churches and chapels during their religious festivals (TorresMartínez 2016). Tourism in Coatepec has increased since 2016, when the town was awarded with the "Pueblo Mágico" distinction ("a town that, through time and in the face of modernity, has conserved, valued and defended its historical, cultural and natural legacy" [Velarde-Valdez et al. 2009:81]). Motivated by this recognition, in the last few years, the construction of floral arches has spread to schools and to some restaurants during the festival (Torres-Martínez 2016). This phenomenon has caused an increased demand for the plants used to create the floral arches. For example, in the neighboring municipality of Xico, it is reported that more than 30 floral arches are constructed every year (Mata-Labrada 2011). In 2008, it was recorded that approximately 70 arches were constructed in the municipalities of Coatepec, Teocelo, Acajete, and Tlalnelhuayocan (Haeckel 2008). The high demand for these resources could diminish the wild populations in the collection sites, as has been suggested by other studies, in which the plants for floral offerings are extracted from increasingly distant locations (Beltrán-Rodríguez et al. 2012; Mata-Labrada 2011, 2013). One of the negative consequences of plant shortage is the substitution of natural materials for artificial elements in the ornamentation of the floral arch. In the state of Hidalgo, the cucharilla has been substituted with plastic or cloth flowers (López-Gutiérrez 2010). Various authors agree that replacement of elements of the arch detracts from the purity and value of the offering in cultural terms (López-Gutiérrez 2010; MendozaZaragoza 2010).

Increased extraction of plant resources can have negative effects on natural populations, including alterations to the physiology, vital rates, and genetic diversity (Ticktin 2004). This has been recorded in Tillandsia macdongallii and T. violaceae (MondragónChaparro and Ticktin 2011), Sabal yapa (Pulido et al. 2007), Euphorbia antisyphilitica (Martínez-Ballesté and Mandujano 2013), Chamaedorea radicalis (Endress et al. 


\section{(f) Ethnobiolocy Letters}

\section{Research Communications}

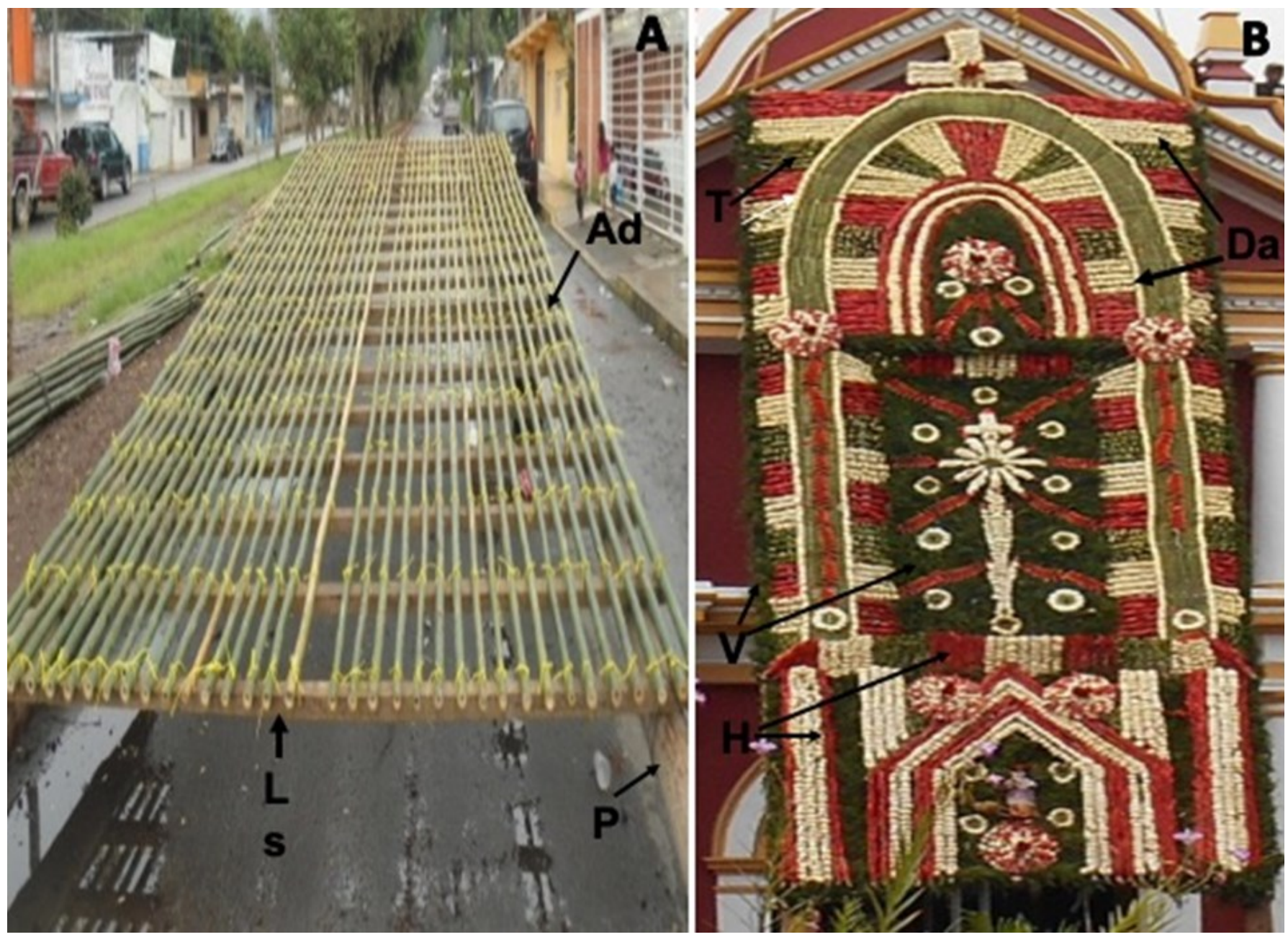

Figure 2 Elements that make up the floral arch: A structure (Arundo donax [Ad], Liquidambar styraciflua [Ls], and Pinus spp. [P]) and B ornamental (leaf and inflorescences of Tillandsia spp. [T], leaf of Dasylirion acrotrichum [Da], Vitis spp. [V], and inflorescences of Heliconia spp. [H]).

2006), Agave potatorum (Torres et al. 2015), Agave inaequidens(Valenzuela-Zapata et al. 2011), and Brahea dulcis (Pavón et al. 2006). Over-extraction has a relatively greater impact on species of slow growth and restricted distribution, as is the case with $D$. acrotrichum.

This study documents the traditional management of $D$. acrotrichum for production of the arco mayor of Coatepec for the patronal festival of San Jerónimo. Of all the plants used in this offering, $D$. acrotrichum is the only one endemic to Mexico (Rzedowski 2006) and is also threatened. Construction of the arch under the direction of the mayordomia is described, and an analysis made of how the system of social organization and locally adopted practices can contribute to in situ conservation and sustainable management of wild plant populations in the sites where they are being extracted.

\section{Methods}

The process of construction of the arco mayor for the festival of San Jerónimo in Coatepec, Veracruz was studied over three years $(2013,2014$, and 2016). The stages followed by the social actors who participate in the management of $D$. acrotricbum were recorded through participant observation and the application of semi-structured interviews (sensu Martin 2000). Twenty -five semi-structured interviews were applied to adult men (between 20-70 years old), whose role is to collect materials and to elaborate the floral arch. In addition, three in-depth interviews were made with the mayordomo, padrinos, and the owner of the site of extraction. 


\section{Study Species}

D. acrotrichum belongs to the family Asparagaceae (Figure 3); it is a perennial, polycarpic, and dioecious plant of slow growth. It has leaves with spines on the edges, grouped into rosettes, which widen at the base, overlapping each other. Each individual can present multiple stems produced through vegetative growth (Bloger 1994). It is distributed in the arid and semiarid zones of Mexico, found on well-drained gravelly soils, on the slopes of hills and gullies of xerophyllous scrub. It is commonly known as "cucharilla", due to the fact that the base of the leaves is whitish, broad and concave, similar to a long-handled spoon.

\section{D. acrotrichum Collection Site}

$D$. acrotrichum was collected in the locality of Alchichica, located on the semiarid high plateau zone of the municipality of Tepeyahualco, in the state of Puebla (19 26' 56.1' 'N $97^{\circ} 22^{\prime} 25.4^{\prime \prime} \mathrm{W}$ and $19^{\circ} 26^{\prime}$ 55.6"N; $97^{\circ} 22^{\prime} 27.1$ 'W; 2337-2407 $\mathrm{m}$ asl). The zone presents hills of limestone and volcanic rock, sandy soils, and a semiarid and generally extreme climate. The vegetation is xerophyllous scrub with succulent plants with leaves in rosettes or concentrated towards the extremes and aphyllous plants, represented mainly by species of the genera Agave, Hechtia, Yucca, Dasylirion, Opuntia, and Euphorbia (Rzedowski 2006).

\section{Results}

Organization for Construction of the Floral Arch Construction of the arco mayor in the patronal festival of Coatepec involves three main actors: the mayordomo, the faeneros (all of whom are male), and the padrinos. Women participate only in the preparation of food, which is offered to the faeneros during the construction of the arch. The mayordomo is responsible for seeking funds for constructing the arch. He also has to coordinate and organize the collection of plant materials, the design and supervision of faeneros' tasks, finding padrinos for the arch, and designing the arch together with the most experienced faeneros. This mayordomia has been passed down among the males of a single family, who have taken charge for the last four generations. The current mayordomo has been in charge since 2006. He is distinguished for constructing aesthetically beautiful arches and for producing the arco mayor in time for the festival. This is why each year, the authorities of the local kindergarten have asked him to produce a smaller, simpler arch for the entrance to the school during the festival of San Jerónimo. The teachers and parents

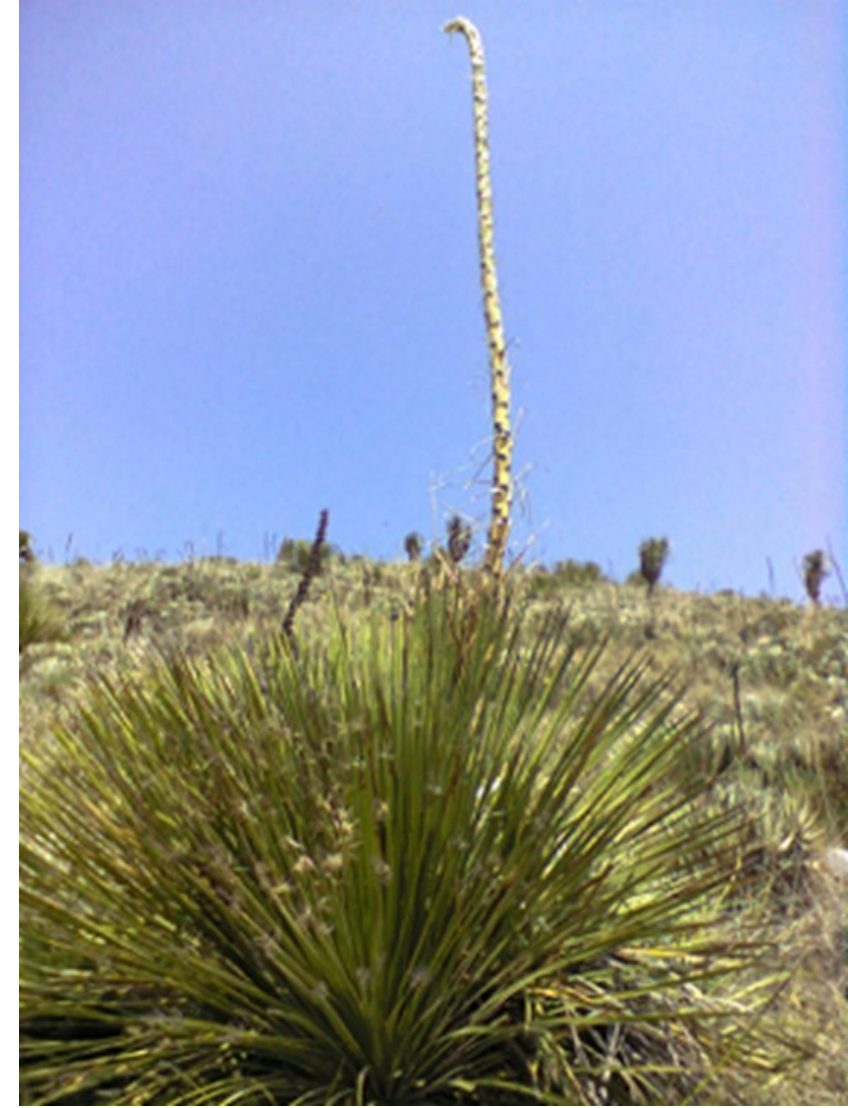

Figure 3 Dasylirion acrotrichum (cucharilla) at Alchichica, Puebla.

wish the students to become familiar with the tradition. Likewise, other families have requested arches to decorate their restaurants' entrances to attract tourists attending the festival.

The faeneros are men (adults, young men, and boys) who participate voluntarily, without receiving payment in the construction of the arch every year. To make the adornments, they collect, process, and clean the plant materials. Their specific activities depend on their experience and abilities. The experienced faeneros oversee collecting the cucharilla and constructing the arch structure and the decoration and design, which depend on the quantity of resources collected. The beginners (generally young men and boys of 10 to 20 years of age) process and clean the plant material and help with the construction of the arch structure.

The padrinos are a Catholic married couple of good moral standing, known by the inhabitants of the neighborhood Los Carriles, which is where the arch is built. They help the mayordomo pay for the food of the faeneros during the construction of the arch, sometimes 
they pay for the gasoline for the vehicles used to collect the plants. They also provide money to buy the aguardiente spirit alcohol offered to the faeneros, to pay for the dancers who participate in the processions and to buy the fireworks that are used during the festival. The padrinos are in charge of blessing the arch and place the first flower to begin its decoration. Economic support for these activities is voluntary; however, these are unavoidable commitments of trust and respect that help to maintain the social fabric of the locality.

\section{Collection of D. acrotrichum}

The site of $D$. acrotrichum extraction for the arco mayor of Coatepec is a private property in Alchichica, Puebla, with an area of 10 ha, where the D. acrotrichum presents a density of 349 individuals per ha. The plants have been collected from this site for approximately 80 years, which is the same period that the family of the current mayordomo has been in charge. For all of that time, there has been an agreement between the mayordomo's family and the owner of the site of extraction, which ensures the supply of "cucharilla" every year. The site owner imposes no limit on the number of specimens collected and does not charge for the extraction (i.e., the mayordomo has free access to the plants). The mayordomo can collect plants to make the arco mayor, as well as the other private arches he is asked for every year. In gratitude, the mayordomo gifts fruits, vegetables, poultry, and large containers of aguardiente to the owner of the land. The quantity of these gifts varies according to the economic resources of the mayordomo and any donations received by the group of faeneros.

Every year, the landowner authorizes the extraction of this plant by at least nine groups of faeneros from different nearby towns that celebrate different religious festivals (four groups from Coatepec, four from Teocelo, and one from Xico). These groups gain access to the site through the recommendation of other arch makers who are friends with the landowner. The landowner shows the arch makers the collection sites and instructs them not to cut the young specimens. To avoid cutting plants unnecessarily, the landowner advises the mayordomo that they should not cut individuals of less than $12 \mathrm{~cm}$ in diameter. Each group collects between 100 and 120 specimens, but the group from Coatepec extracts a greater quantity (at least 250 specimens every year). The annual mean collection at this site is
$1117( \pm 42.3)$ plants. In addition, there are groups of faeneros that have no agreement regarding access to the plants; therefore, they may ask the mayordomo to collect more specimens for them and, in this way, they obtain the cucharilla.

Other groups of faeneros, having no extraction agreement with the landowner, and conduct clandestine collections in which they cut individuals in the juvenile stage (less than $12 \mathrm{~cm}$ in diameter). These plants have narrow, fragile leaves considered unsuitable for adorning the arches and are therefore rejected. Clandestine collection of plants has led to other owners of sites in Alchichica, Puebla, with $D$. acrotrichum refusing access for extraction to any faeneros, even those that are legitimately organized.

In order to collect the $D$. acrotrichum, the mayordomo and 25 or 30 faeneros travel to Alchichica. They are organized into groups formed by a cutter, a tier, and a carrier. Only the most experienced select and cut the suitable plants (adults of diameter greater than $12 \mathrm{~cm}$ ). The cutter must cut the plants from the base of the stem, extracting complete specimens, the tier ties the cut leaves of the plant, and the carrier carries them to the vehicles for transportation to the house of the mayordomo in Coatepec. There is a belief that red is an unlucky color and can cause the plants to turn dark brown, losing their characteristic ivory tone; for this reason, it is not permitted to wear red garments during collection. Indeed, even the food they eat should not have any ingredients of this color. Being subject to menstruation, the women are also thought to cause discoloration of the plants and, this is why, only men participate in this process.

After the collection is complete, they make some adornments with cucharilla in the form of a crown that are placed on the vehicles' hood so that people know that they are bringing plants for the arch on the road back to Coatepec. The mayordomo and the faeneros are received with fireworks to announce their arrival. The collected D. acrotrichum plants are unloaded and guarded in the house of the mayordomo. Finally, a meal is provided for the faeneros to thank them for their participation in the collection.

\section{Processing of $D$. acrotrichum}

In order to extract the "cucharilla," it was observed that the mayordomo organized a group of faeneros to be in charge of removing the "heart" (stem of the plant) of each of the individuals (Figure 4a). The faeneros tear out the leaves and thus eliminate the spines (Figure 

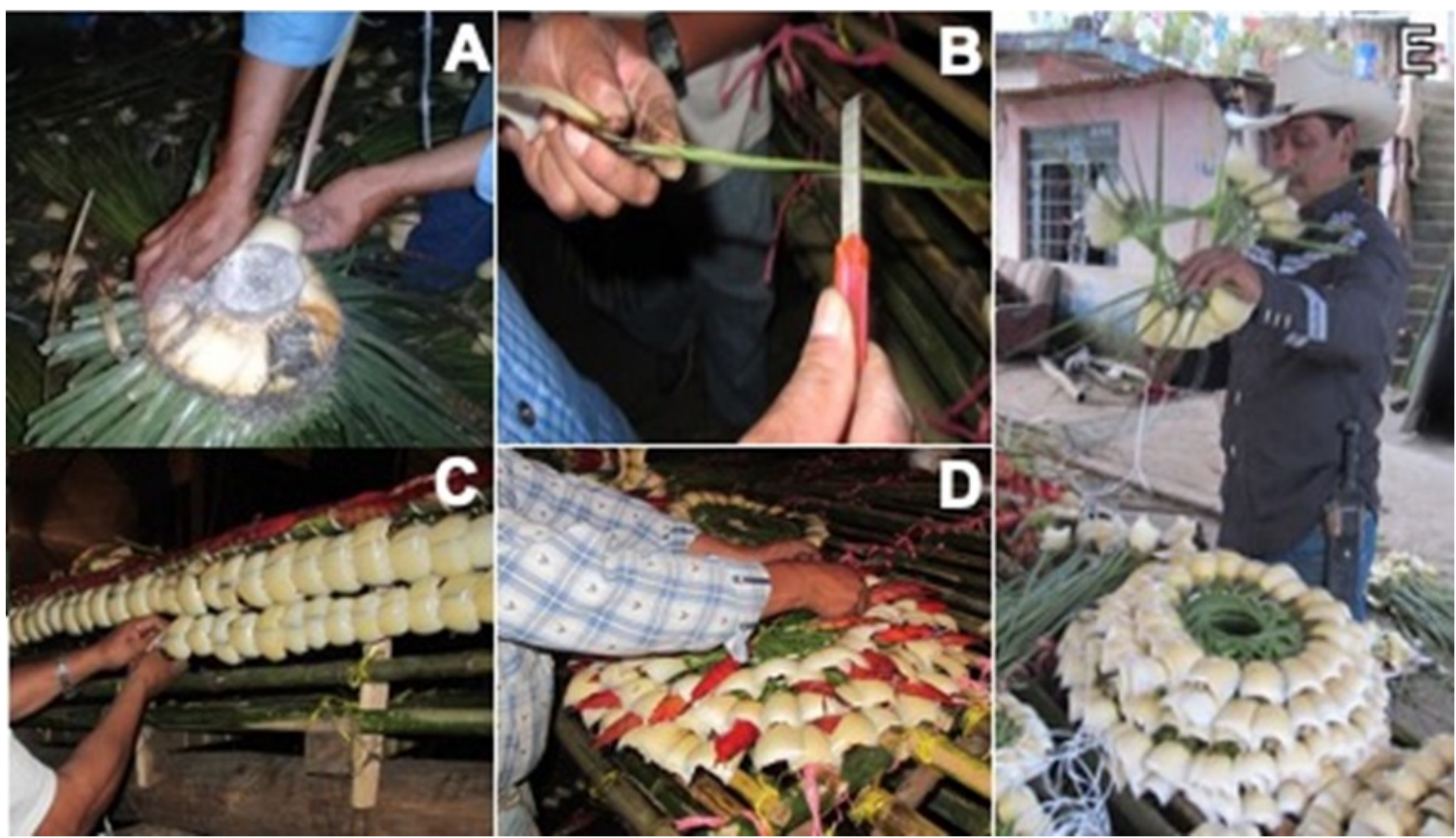

Figure 4 Processing of $D$. acrotrichum plants to decorate the floral arch. A Obtaining leaves (cucharilla), B removal of spines from the margin of the leaves, and C-E preparation of ornaments and placement in the arch.

4b). From a stem of $16 \mathrm{~cm}$ in diameter, 80 or 90 cucharillas can be extracted, while one of $12 \mathrm{~cm}$ will produce between 50 and 60 . Around $60 \%$ of each plant is used, corresponding to the external leaves that are thicker and firmer and thus more resistant to the heat and light of the sun.

Construction of the Arco Mayor and the Patronal Festival of San Jerónimo

The main arch is $12.5 \mathrm{~m}$ in height and $3.60 \mathrm{~m}$ in width, weighs approximately three tonnes and is constructed in front of the house of the mayordomo. It is constructed from posts of pine and rods of bamboo and liquidambar, which are held in place with vines to form the main structure. The adornments are made from cucharillas (Figure 4C-E), bromeliad inflorescences, heliconias, and cypress branches.

Once all of the materials have been collected and the main structure is complete, on September 24, the padrinos place the "first flower," which consists of a bouquet made of cucharilla and the inflorescence of a tencho (bromeliad), on a wooden cross that will be fixed to the upper part of the finished arch. Afterwards, the padrinos bless the cross and the main structure with flowers so that the next day the faeneros can decorate the offering. This activity is known as "florear el arco." The most experienced faeneros construct the most complex adornments, while the younger men interweave the other materials onto the main structure. Only a decade ago, the design would have determined the quantity of materials to be collected. Now, however, the mayordomo designs the arch depending on the quantity of plant materials they were able to collect that year. To construct the offering, the faeneros use nails, wire, and ropes, which are hidden beneath the adornments. In this way, the structure of the arch is firmer and more stable and the decoration more securely fixed.

The number of floral arches constructed during the festival of San Jerónimo varies. Arches of more than two tonnes are constructed, as well as examples that weigh between 60 and 70 kilos $(1.20 \times 2.20 \mathrm{~m})$, so that they can be carried by groups of children that participate in this activity. In 2013, 14 arches were constructed. In 2015, 11 were constructed, including the arco mayor. In 2016, 15 arches were constructed, of which nine were large and six were small. 
Finally, on September 29, the arco mayor is completed and a mass is celebrated to bless all the arches during the patronal festival. A procession is then held, known as "la bajada de los arcos," presided over by an image of San Jerónimo. The arco mayor, which is carried on the shoulders of the faeneros to the parish church to frame the main entrance. Twenty days later, it is removed and carried back to the mayordomo's house for dismantling. The pine posts and liquidambar beams are stored to be reused for the arch for the following year.

Conservation of D. acrotrichum

The faeneros and the mayordomo believe that San Jerónimo ensures the supply of cucharillas each year for the construction of the arch for the patronal festival. They explained that their extraction practices are appropriate, since the method has not changed in decades and they continue to collect specimens of $D$. acrotrichum. The mayordomo indicated that they impose internal rules that help maintain the plant populations under extraction; the experienced faeneros cannot extract juvenile plants or those of small diameter (less than $12 \mathrm{~cm}$ ). In addition, during collection, the mayordomo dictates the number of plants to collect.

\section{Discussion}

The mayordomias tradition in Mexico commonly consist of a mayordomo, whose responsibility is usually held for one year. The position is rotational, and with no re-election (Carrasco 1991; Gómez-Arzapalo 2010). This system of responsibilities varies among different communities: there can be more than one mayordomo and the duration and functions differ among sites (Montalvo-Nolasco and Heredia Barrera 2015). According to the current mayordomo, one family has had the duty for more than 80 years. The reason is that no one else has requested the position on account of the great responsibility it implies. The mayordomo stated that: "It is not easy to find the materials and cover the economic costs of construction of the arch, or to finish the offering in time and look after the physical integrity of the faeneros."

This mayordomia contrasts with the original aim of this type of social organization that, by being rotational, avoids the accumulation of wealth and monopolization of power by distributing the costs of parties and ceremonies, as well as the various obligations (Korsbaek 1987). This concurs with other studies, in which some families in Mexican villages accumulate wealth or make a greater economic effort in order to keep themselves in that position, excluding other families without losing the political and religious benefits and the reputation that the position offers (Korsbaek 1987). Concentration of the mayordomia in a single family for such a long period of time can present some risks; for example, there is a danger that the technical knowledge accumulated over such a long time in terms of the traditional management of the plants (including collection methods, forms of construction of the floral arch, and agreements with the owners of sites from which the plants can be extracted) may not be fully transmitted to other families or to new generations. There are three reasons that might explain why the mayordomia is not held on a rotation basis in Coatepec: 1) few people are granted access to the collection sites, mainly because it has to do with personal rather than community agreements; 2) the economic costs are high (which demotivates other community members' participation), and the mayordomo has to assume the social responsibilities derived from administering the money involved, that includes donations, and protecting the materials and the participants, 3) there is a lack of leadership and little skill in the general organization of the people involved (donors, workers, and padrinos).

Construction of floral arches has increased in recent years in central Veracruz; new chapels and churches are built for which these offerings are required. Thus, new groups of faeneros are formed, generally of young adults who have not adopted the organization system; nor do they have agreements with extraction site owners to utilize the correct methods of plant selection and extraction (Haeckel 2008). These groups are therefore forced to carry out clandestine collection of $D$. acrotrichum, cutting specimens in the juvenile state with diameters of less than $12 \mathrm{~cm}$ that do not provide cucharillas with suitable characteristics. This practice affects the population dynamics of the species by extracting adult and juvenile individuals that have not yet contributed to the maintenance of the wild populations and thus reducing the establishment of seedlings (Ticktin 2004; Torres-Martínez 2016). In extraction sites, TorresMartínez (2016) reported a decrease in adult and seedling density. Moreover, asexual reproduction has exceeded sexual reproduction, which could in turn lead to a reduction in the genetic variability of populations, as reported in other species (MartínezBallesté and Mandujano 2013; Ticktin 2004). For the above stated reason, the faeneros would have to replace 
the cucharillas for other elements. This has been the case in some of Hidalgo's communities where synthetic materials are used for the floral arches (López-Gutiérrez 2010). By not using the plant in the traditional way, as has hitherto been the case, the intangible elements of the ritual that act to confer a religious sense of sacredness to nature, could be lost (Madrazo and Urdapilleta 2008), especially considering that each of the floral elements, like leaves and flowers represents different symbols associated with agricultural cycles and with the sacredness of nature (Espejo et al. 1994). Although data on the ritual and sacred qualities of this tradition were not expressly collected, it should be noted that both the mayordomo and faeneros explained that replacing any material from the arch would lessen its value. Therefore, to alter the composition of the arch would mean eliminating the sacrifice made to collect that materials for the offering. This could indicate that those involved in the ritual give special weight to the floral arches, and this viewpoint has little to do with a modern utilitarian attitude towards biodiversity.

The expansion of tourism to Coatepec could represent a pressure for an increased fabrication of floral arches, which are now installed not only for ritual purposes, but also to decorate restaurants, schools, and businesses. Although the Pueblos Mágicos program has been considered a success in many places, in others it has caused social, economic, and demographic problems, also affecting the natural surroundings (Equihua-Elias et al. 2015). The latter undoubtedly receives little attention in the planning and evaluation of the Pueblos Mágicos, whereby the negative impacts of tourism on natural resources and traditions are not considered or analyzed (EquihuaElias et al. 2015). In some of these towns, specific natural resources and derived products are now in great demand with no consideration given to their state of conservation and distribution (Pavón et al. 2006). That is why it is argued that population ecological studies are essential to determine extraction rates without putting species' viability at risk (Martínez-Ballesté and Mandujano 2013). Moreover, it draws attention to studies designed to transcend disciplinary barriers, where methods, research tools, knowledge fields, and epistemological approaches coming from areas such as anthropology, economics, politics, sociology, and others, are equally valued. However, it is especially key to address power relations in the way knowledge is produced within modern societies, where citizens and local communities should be more actively engaged, if the aim is to achieve more sustainable management practices (Peterson et al. 2010). Local actions that ensure biodiversity conservation through sustainable management practices should be part of the Pueblos Mágicos' regulations. In this way, tourism and traditions can develop under context-specific, socially and environmentally responsible conservation schemes.

In Coatepec, from the late 1980s, the shortage of resources used for the arco mayor has been notable (Torres- Martínez 2016). Because of this, the design of the offering has had to be adapted to the availability of the plants they have collected, while still conserving the original elements. Despite this, the mayordomo and the faeneros consider that the supply of $D$. acrotrichum will be ensured by San Jerónimo and that their collection techniques are suitable in terms of caring for the wild populations. However, in extraction sites, there is a lower number of reproductive individuals, lower floral production, and reduced recruitment of new individuals per seed compared to sites where no collection takes place (Torres-Martínez 2016). For this reason, it is necessary to find spaces of discussion and mutual learning where community beliefs converge with scientific knowledge, so that the best decisions associated with the ritual itself and the species' conservation, can be taken. Other studies (Garibaldi and Turner 2004; Infield and Mugisha 2013; Peterson et al. 2010), highlight the value of considering the biocultural dimension as a mechanism for giving continuity to cultural expressions and favoring the long-term conservation of biodiversity.

The floral arch tradition represents a link between culture, social organization, and nature. This scenario strengthens the sense of territory and the heterogeneous use of the landscape; it reaffirms the social fabric, as well as the local and regional identity in a celebration where all can participate. The mayordomias and the patronal festivals reassure and preserve cultural values, identity, and social interaction (Wilsey and Nelson 2008).

For the above stated reasons, it is necessary to find new, more efficient ways to collect $D$. acrotrichum. Collection should be done following fallow periods and rotation of the collection sites. The right amount of plants should be accounted for, to avoid unnecessary waste and the death of reproductive adults. Additionally, it is crucial to improve communication among community leaders, faeneros' 
groups, independent archers, researchers, technicians, and government decision makers in the forestry department to ensure that decisions will be made collaboratively between everyone involved. A census of all the archers dedicated to this activity can be useful to establish clear regulations around access to the sites as well as to have control over the number of plants extracted. These actions should be oriented towards decreasing the incidence of clandestine collection. Finally, in order to achieve recovery of the extraction zones, collaboration networks and educational programs should be developed with the owners of $D$. acrotrichum distribution sites, with the long-term aim to produce locally relevant, participatory, citizen led restoration plans.

\section{Acknowledgments}

This study was carried out thanks to information provided by the mayordomo and the faeneros of the arco mayor of Coatepec and the owner of the D. acrotrichum collection site, who kindly responded to all questions asked and allowed observation of the entire process involved in the fabrication of the arco mayor.

\section{Declarations}

Permissions: This study was conducted during fieldwork and the interviews with permissions from the mayordomo and the faeneros of the arco mayor of Coatepec.

Sources of funding: This work was supported by a scholarship to G. Torres-Martínez provided by Consejo Nacional de Ciencia y Tecnología (CONACyT) (294281).

Conflicts of Interest: None declared.

\section{References Cited}

Beltrán-Rodríguez, L. A., B. Martínez-Rivera, and A. Paulo-Maya. 2012. Etnoecología de la Flor de Catarina Laelia autumnalis (La llave Et Lex. Lindl.) (Orchidaceae) en una Comunidad Campesina al Sur del Estado de Morelos, México: Conservando un Recurso y Preservando Saberes Populares. Etnobiología 10:1-17.

Bogler, D. J. 1994. Taxonomy and Phylogeny of Dasylirion (Nolinaceae). Doctoral Dissertation, The University of Texas, Austin, TX.

Carrasco, P. 1991. Sobre el Origen Histórico de la Jerarquía Político-ceremonial de las Comunidades Indígenas, In Historia, Antropología y Politica. Homenaje a Ángel Palermo, edited by M. Suárez, pp. 306-326.
Universidad Iberoamericana y Alianza Editorial Mexicana, México.

Chiva-Beltrán, J. 2012. Arcos Efímeros Mexicanos. De la Herencia Hispana al Nacionalismo Artístico. Ciencias Sociais e Humanidades 24:193-212.

Endress, B. A., D. L. Gorchov, and E. J. Berry. 2006. Sustainability of a Non-timber Forest Product: Effects of Alternative Leaf Harvest Practices Over 6 Years on Yield and Demography of the Palm Chamaedorea radicalis. Forest Ecology and Management 234:181-191. DOI:10.1016/j.foreco.2006.07.020.

Equihua-Elias, G. C., S. R. Messina Fernandez, and J. P. Ramírez-Silva. 2015. Los Pueblos Mágicos: Una Visión Crítica Sobre su Impacto en el Desarrollo Sustentable del Turismo. Revista Fuente 22:2-7.

Espejo, A., I. Ramírez, and N. Cuevas. 1994. Diccionario Mítico-Mágico de Veracruz: Gobierno del Estado de Veracruz. Xalapa, Veracruz, México.

Garibaldi, A., and N. Turner. 2004. Cultural Keystone Species: Implications for Ecological Conservation and Restoration. Ecology and Society 9:1. DOI: 10.5751/ES-00669-090301.

Gómez-Martínez, A. 2013. Las Ofrendas Aritméticas entre los Nahuas de la Huasteca Veracruzana. In Convocar a Los Dioses: Ofrendas Mesoamericanas, edited by J. Broda, pp. 171-200. Instituto Veracruzano de la Cultura. Xalapa, Veracruz, México.

Gómez-Arzapalo, R. A. 2010. Los Santos y sus Ayudantes. Mayordomías en Xalatlaco,México. Reproducción Cultural en el Contexto de la Religiosidad Popular. Gazeta de Antropología 26:5.

Haeckel, I. B. 2008. The "Arco Floral”: Ethnobotany of Tillandsia and Dasylirion spp. in a Mexican Religious Adornment. Economic Botany 62:90-95. DOI:10.1007/s12231-008-9009-8.

Infield, M., and A. Mugisha. 2013. Culture, Values and Conservation: A review of Perspectives Policies and Practices. Fauna \& Flora International, Cambridge, UK.

Korsbaek, L. 1987. El Desarrollo del Sistema de Cargos de San Juan Chamula: El Modelo Teórico de Gonzalo Aguirre Beltrán y los Datos Empíricos. Anales de Antropología 24:215-242.

López-Gutiérrez, B. N. 2010. Etnobotánica de Dasylirion acrotriche (Schiede) Zucc. (Nolinaceae), en Áreas del Centro y Sur del Estado de Hidalgo, 
México. Master's Thesis, Universidad Autónoma del Estado de Hidalgo, Hidalgo, México.

Madrazo, M. M., and M. M. Urdapilleta. 2008. La Fiesta Patronal de Xico, Veracruz. Tradición Oral y Festividad. Universidad Autónoma del Estado de México. Ciencia ergo sum 15:9-20.

Martin, G. J. 2000. Etnobotánica, Manual de Métodos. Editorial Nordan-Comunidad, Montevideo, Uruguay.

Martínez-Ballesté, A., and M. C. Mandujano. 2013. The Consequences of Harvesting on Regeneration of a Non-timber Wax Producing Species (Euphorbia antisyphilitica Zucc.) of the Chihuahuan Desert. Economic Botany 67:121-136. DOI:10.1007/s12231013-9229-4.

Mata-Labrada, F. 2011. La Utilización de la Flora y la Religiosidad en Tequila, Veracruz: Un Estudio Etnohistórico e Interdisciplinario de un Pueblo Enclavado en el Bosque Mesófilo de Montaña. Master's Thesis, Escuela Nacional de Antropología e Historia, México.

Mata-Labrada, F. 2013. Etnografía y Ecología en Relación al Uso Ritual y Ceremonial de Tres Especies Botánicas: Gaultheria acuminata, Dasylirion acrotriche y Tillandsia usneoides. In Naturaleza-Sociedad, Reflexiones desde la Complejidad, edited by F. A. Conde, P. A. Ortiz, A. Delgado, and F. Gómez, pp. 151-158. Universidad Autónoma de Tlaxcala, México.

Mendoza-Zaragoza, M. 2010. El Arte Floral en las Crónicas del Altiplano Central de México del Siglo XVII (Registro Documental e Iconográfico). Master's Thesis, Facultad de Filosofía y Letras. Universidad Nacional Autónoma de México, México.

Mondragón-Chaparro, D., and T. Ticktin. 2011. Demographic Effects of Harvesting Epiphytic Bromeliads and an Alternative Approach to Collection. Conservation Biology 25:797-827. DOI:10.1111/j.1523-1739.2011.01691.x.

Montalvo-Nolasco, P., and L. Heredia Barrera. 2015. Xochitlalli, Mayordomia, Todos Santos, Ritos Funerarios y Cosmovisión en San Juan del Rio (hoy Rafael Delgado), Veracru\%: Instituto Veracruzano de la Cultura. Veracruz, México.
Pavón, N. P., R. I. Escobar, and R. Ortiz-Pulido. 2006. Extracción de la Palma Brabea dulcis en una Comunidad Otomí en Hidalgo, México. Efecto sobre Algunos Parámetros Poblacionales. Interciencia 31:57-61.

Peterson R. B., D. Russell, P. West, and J. P. Brois. 2010. Seeing (and Doing) Conservation Through Cultural Lenses. Environmental Management 45:5-18. DOI:10.1007/s00267-008-9135-1.

Pulido, M. T., T. Valverde, and J. Caballero. 2007. Variation in the Population Dynamics of the Palm Sabal yapa in a Landscape Shaped by Shifting Cultivation in the Yucatan Peninsula, Mexico. Journal of Tropical Ecology 23:139-149. DOI:10.1017/ S0266467406003877.

Rzedowski, J. 2006. Vegetación de México. Digital edition, Comisión Nacional para el Conocimiento y Uso de la Biodiversidad, México. Available at: http://www.biodiversidad.gob.mx/publicaciones/ librosDig/pdf/VegetacionMx_Cont.pdf. Accessed on October 10, 2015.

Ticktin, T. 2004. The Ecological Implications of Harvesting Non-timber Forest Products. Journal of Applied Ecology 41:11-21. DOI:10.1111/j.13652664.2004.00859.x

Torres, I., A. Casas, E. Vega, M. Martínez-Ramos, and A. Delgado-Lemus. 2015. Population Dynamics and Sustainable Management of Mezcal Agaves in Central México: Agave potatorumin TehuacánCuicatlán Valley. Economic Botany 69:26-41. DOI:10.1007/s12231-014-9295-2.

Torres-Martínez, G. 2016. Manejo Tradicional de Dasylirion acrotrichum (Schiede) Zucc (Asparagaceae) para la Elaboración de Arcos Florales en el Centro de Veracruz y la Evaluación del Impacto en sus Poblaciones Naturales. Master's Thesis, Centro de Investigaciones Tropicales, Universidad Veracruzana, Xalapa, Veracruz, México.

Valenzuela-Zapata, A., I. Lopez-Muraira, and M. S. Gaytán. 2011. Traditional Knowledge, Agave inaequidens (Koch) Conservation, and the Charro Lariat Artisans of San Miguel Cuyutlán, Mexico. Ethnobiology Letters 2:72-80. DOI:10.14237/ ebl.2.2011.24. 
Velarde-Valdez, M., A. V. C. Maldonado Alcudia, and M. C. Maldonado Alcudia, M. Candelaria. 2009. Pueblos Mágicos. Estrategia para el Desarrollo Turístico Sustentable: Caso Sinaloa. Teoría y Praxis 6:79-93.
Wilsey, D. S., and K. C. Nelson. 2008. Conceptualizing Multiple Nontimber Forest Product Harvest and Harvesting Motivations Among Balsam Bough Pickers in Northern Minnesota. Society and Natural Resources 21:812-827. DOI:10.1080/089419207 01651204. 